\title{
Athletic Trainers' Perceptions and Frequency of Use of Health Care Core Competencies
}

\author{
Daniel C. Waterman Jr \\ Indiana State University, Dan@variablemovement.com \\ Cailee E. Welch Bacon \\ A.T. Still University, cwelch@atsu.edu \\ Julie M. Cavallario \\ Old Dominion University, jcavalla@odu.edu \\ Lindsey E. Eberman \\ Indiana State University, lindsey.eberman@indstate.edu
}

Follow this and additional works at: https://nsuworks.nova.edu/ijahsp

Part of the Medicine and Health Sciences Commons

\section{Recommended Citation}

Waterman DC, Welch Bacon CE, Cavallario JM, Eberman LE. Athletic Trainers' Perceptions and Frequency of Use of Health Care Core Competencies. The Internet Journal of Allied Health Sciences and Practice. 2021 Oct 01;19(4), Article 16.

This Manuscript is brought to you for free and open access by the College of Health Care Sciences at NSUWorks. It has been accepted for inclusion in Internet Journal of Allied Health Sciences and Practice by an authorized editor of NSUWorks. For more information, please contact nsuworks@nova.edu. 


\title{
Athletic Trainers' Perceptions and Frequency of Use of Health Care Core Competencies
}

\begin{abstract}
Purpose: Core competencies (CCs) have been standard for all health care professions since 2001 but have only recently been integrated into professional-level education in athletic training. Currently, there is no research showing perceptions or frequency of use in various subgroups of athletic trainers based on experience. Method: We evaluated athletic trainer (AT) perceptions and frequency of use of CCs and perceived preparedness by professional-level education. A cross-sectional web-based survey was completed by 644 clinically practicing ATs. The survey included demographics ( 5 items), perceived use for CCs (22 items), perception of educational preparedness (6 items), and perceived frequency of use within patient encounters (PEs; 6 items). Data Analysis: Descriptive statistics were calculated for overall perception of importance and frequency of use in clinical practice. We conducted a one-way ANOVA to compare perceived preparedness for each of the CCs on years of experience (5 year intervals up to 25+). Results: ATs strongly agreed patient-centered care is important to their clinical practice $(P C C G M=3.59 \pm 0.630$, Mode $=4)$ with frequent use in $85.0 \pm 21.8 \%$ of their PEs. Evidence-based practice had the lowest perceived importance (EBPGM=3.38 \pm 0.581 , Mode=3), but is still frequently used $(73.3 \pm 25.6 \%)$. ATs agreed interprofessional and collaborative practice is important (IPCPGM $=3.42 \pm 0.683$, Mode $=3$ ) but integration into practice was low $(67.0 \pm 27.7 \%)$. Health care informatics is important (HITGM=3.21 \pm 0.657 , Mode $=3)$ and frequently used in PEs $(70.8 \pm 28.9 \%)$. Participants strongly agreed quality improvement is important (QIGM=3.42 \pm 0.562 , Mode $=4$ ); however, is the least often used $(66.1 \pm 26.27 \%)$. ATs strongly agreed professionalism (PROF) is important (PROFGM $=3.42 \pm 0.562$, Mode $=4$ ) and frequently used in PEs $(85.9 \pm 22.9 \%)$. We identified significant differences between years of experience intervals and educational program preparation to integrate the CCs into practice. ATS that more recently completed their professional education felt more prepared. Conclusions: ATs find CCs important in practice and ATs who have less than 10 years of experience largely believe their programs have adequately prepared them. More work needs to be done to create and deliver professional development to prepare ATs to integrate CCs into practice.
\end{abstract}

\section{Author Bio(s)}

Daniel C. Waterman, DAT, LAT, ATC, is a graduate of the Doctorate in Athletic Training Program at Indiana State University.

Cailee Welch Bacon, PhD, ATC Cailee Welch Bacon is an associate professor for the athletic training programs and a research associate professor for the School of Osteopathic Medicine in Arizona at A.T. Still University.

Julie Cavallario, PhD, LAT, ATC is an Assistant Professor in the Department of Rehabilitation Sciences at Old Dominion University. She is the Program Director for the Masters of Science in Athletic Training Program

Lindsey E. Eberman, PhD, LAT, ATC is a Professor and Program Director of the Doctor of Athletic Training Program at Indiana State University.

\section{Acknowledgements}

We would like to thank the Indiana State University Graduate Student Research Fund and the Maine Athletic Trainers' Association for helping to fund this research. 


\title{
IIIAHSP \\ The Internet Joumnal of Allied Health Sciences and Practice \\ Dedicated to allied health professional practice and education \\ Vol. 19 No. 4 ISSN 1540-580X
}

\section{Athletic Trainers' Perceptions and Frequency of Use of Health Care Core Competencies}

\author{
Daniel C. Waterman ${ }^{1}$ \\ Cailee E. Welch Bacon² \\ Julie M. Cavallario ${ }^{3}$ \\ Lindsey E. Eberman ${ }^{1}$ \\ 1. Indiana State University \\ 2. A. T. Still University \\ 3. Old Dominion University \\ United States
}

\begin{abstract}
Purpose: Core competencies (CCs) have been standard for all health care professions since 2001 but have only recently been integrated into professional-level education in athletic training. Currently, there is no research showing perceptions or frequency of use in various subgroups of athletic trainers based on experience. Method: We evaluated athletic trainer (AT) perceptions and frequency of use of CCs and perceived preparedness by professional-level education. A cross-sectional web-based survey was completed by 644 clinically practicing ATs. The survey included demographics ( 5 items), perceived use for CCs (22 items), perception of educational preparedness ( 6 items), and perceived frequency of use within patient encounters (PEs; 6 items). Data Analysis: Descriptive statistics were calculated for overall perception of importance and frequency of use in clinical practice. We conducted a one-way ANOVA to compare perceived preparedness for each of the CCs on years of experience (5 year intervals up to 25+). Results: ATs strongly agreed patient-centered care is important to their clinical practice $\left(P C C_{G M}=3.59 \pm 0.630\right.$, Mode $\left.=4\right)$ with frequent use in $85.0 \pm 21.8 \%$ of their PEs. Evidence-based practice had the lowest perceived importance $\left(E B P_{G M}=3.38 \pm 0.581\right.$, Mode=3), but is still frequently used $(73.3 \pm 25.6 \%)$. ATs agreed interprofessional and collaborative practice is important $\left(I P C P_{G M}=3.42 \pm 0.683\right.$, Mode=3) but integration into practice was low $(67.0 \pm 27.7 \%)$. Health care informatics is important $\left(H I T_{G M}=3.21 \pm 0.657\right.$, Mode=3) and frequently used in PEs $(70.8 \pm 28.9 \%)$. Participants strongly agreed quality improvement is important $\left(Q I_{G M}=3.42 \pm 0.562\right.$, Mode $\left.=4\right)$; however, is the least often used $(66.1 \pm 26.27 \%)$. ATs strongly agreed professionalism (PROF) is important $\left(P R O F_{G M}=3.42 \pm 0.562\right.$, Mode $\left.=4\right)$ and frequently used in PEs $(85.9 \pm 22.9 \%)$. We identified significant differences between years of experience intervals and educational program preparation to integrate the CCs into practice. ATS that more recently completed their professional education felt more prepared. Conclusions: ATs find CCs important in practice and ATs who have less than 10 years of experience largely believe their programs have adequately prepared them. More work needs to be done to create and deliver professional development to prepare ATs to integrate CCs into practice.
\end{abstract}

Keywords: Clinical Practice, Professional Development, 


\section{INTRODUCTION}

Athletic training, as a health care profession, is rapidly advancing educational standards for certification. Athletic training is recognized by the American Medical Association (AMA) as a health care profession and has been since 1990.1,2 Since that time, there has been a gradual and substantial advancement of the educational requirements necessary for athletic training certification. In less than 20 years, the governing bodies of athletic training have moved from an internship only pathway for certification to now needing an advanced degree starting in $2022 .{ }^{3}$ This shift has been incremental with internship routes to certification ending in 2001, with entry level undergraduate degrees required for certification following. ${ }^{1-3}$ There are now new standards that mandate entry to the profession occurs at the Master's degree. ${ }^{4}$ With this evolution occurring over the last two decades, it has led to variable levels of athletic trainer (AT) experience and education. As of November of 2019, there are around 50,000 certified ATs in the United States. ${ }^{5}$ Of these 50,000 ATs, it can be assumed there is a wide breadth of educational experiences and clinical experiences based on the changes made within the last 20 years.

Athletic trainers are governed by the Board of Certification (BOC), a national agency which determines the standards of professional practice that all athletic trainers must practice by. ${ }^{6}$ These standards of professional practice include recommendations by the National Academy of Medicine's (NAM), formerly the Institute of Medicine, recommendation of using core competencies (CC) for all health care providers. ${ }^{7}$ Into the Quality Chasm has served as a template for all health care providers to give quality patient care for decades. ${ }^{7}$ The NAM divided the CC into five areas, Evidence Based Practice (EBP), Patient Centered Care (PCC), Interprofessional Collaboration and Education (IPCP), Quality Improvement (QI), and Health Care Informatics and Technology (HIT). ${ }^{7}$ The focus of the report by the Institute of Medicine in 2001 was to create a set of CC for all health care providers to follow in order to ensure efficient, effective, safe and equitable patient care. ${ }^{7}$ This philosophy has been further expanded by the "Quadruple Aim."8 Initially the "triple aim", which was first introduced in 2008 by the Institute for Health Care Improvement, the purpose is to improve patient outcomes by 1) improving patient experience, 2) improving health of the population, and 3) reducing health care capital costs. ${ }^{9} \mathrm{~A}$ fourth aim was added to incorporate provider wellness in order to reduce provider burnout and improve patient care. ${ }^{8}$ The NAM health care competencies and Quadruple Aim of health care are widely accepted and used standards for health care providers. 8,9 As athletic training shifts into graduate education, the Commission on Accreditation of Athletic Training Education (CAATE) has implemented significant structural changes in the 2020 educational standards to further align with NAM health care competencies and Quadruple Aim. ${ }^{10}$ The 2020 CAATE competencies include 1) Evidence based practice, 2) PCC, 3) HIT, 4) QI, 5) IPCP, and 6) Professionalism (PROF). ${ }^{10}$ These standards align with other health care educational11,12 and professional clinical practice standards. ${ }^{7-9,11-17}$

Implementation research suggests it takes 17 years for research to reach clinical practice. ${ }^{18}$ With the NAM "Into the Quality Chasm" report produced in 2001, we should start seeing implementation of these health care competency recommendations being used within all patient encounters within athletic training. 7,18 To date, there have been no studies that evaluate the widespread perception of or frequency of use of the CCs among practicing ATs. The purpose of this study was to evaluate perceptions and frequency of use of the CCs, as well as compare these perceptions and frequencies between ATs with varying years of experience.

\section{METHODS \\ Design}

This study was approved as exempt research by the university institutional review board. We used a cross-sectional research design to evaluate the perceptions and frequency of use of CCs among clinically active ATs.

\section{Participants}

We recruited ATs who were in good standing with the National Athletic Trainers' Association (NATA) at the time of data collection. Using the NATA Research Survey Service, we randomly targeted potential participants based on their previously identified willingness to receive research surveys. ATs who actively had a patient panel and were clinically practicing or were clinically practicing prior to the COVID-19 pandemic were included in the study. The survey was distributed to 7440 potential participants by the NATA Survey Service on our behalf. A total of 674 participants accessed the questionnaire $(9.1 \%$ access rate). Of the 674 participants who accessed the questionnaire, 644 respondents completed the survey in its entirety (95.5\% completion rate). Respondents provided informed consent by clicking "I agree to participate" and then navigated through the remainder of the survey. Participants could withdraw or skip questions at any time.

\section{Instrumentation}

With permission, we used a validated survey from a previous study. ${ }^{19}$ The original tool was a 39 -item web-based survey (Qualtrics ${ }^{\circledR}$, Provo, UT), which assessed post-professional athletic training students' perceptions and frequency of use of the core competencies. We modified the original survey language to address practicing ATs and all modifications were reviewed by 2 survey 
research experts to ensure content and face validity had not been affected. The survey addressed demographics (5 items), perceived use of CCs (22 items), perception of educational preparedness ( 6 items), and perceived frequency of use regarding the CCs during patient encounters ( 6 items). To gain the participants perceptions of how they use a particular competency during a patient encounter, the definition of the core competency was provided at the top of the screen. Next, items were rated on a 4-point Likert scale: strongly disagree (1), disagree (2), agree (3), and strongly agree (4) in relation to how the participant perceived themselves using aspects of that $\mathrm{CC}$. Then, there was one question regarding the participant's feelings towards how their professional educational experience prepared them to use that CC in practice. Finally, a single item sliding scale from 0-100 was used to record the percentage of time the participant implemented that $\mathrm{CC}$ into every patient encounter. This process was repeated for all 6 CCs.

\section{Procedures}

The survey was scheduled to be sent on Tuesdays for 8 weeks through April and May 2020, with reminders sent biweekly to those participants who had not yet submitted the survey. The data was collected until 10 days after the last email was sent. The surveys were collected and stored in Qualtrics ${ }^{\circledR}$, de-identified by the NATA, and sent to the research team for statistical analysis. Mean time to complete the survey was 706.5 seconds (SD $\pm 766 \mathrm{~s}$ ), or just under 12 minutes.

\section{Statistical Analysis}

We used descriptive statistics to identify characteristics of central tendency (mean, mode, standard deviation, frequencies) as well as one-way ANOVA of subgroup demographics to examine relationships among multiple subgroups of participants based on years of experience. Six subgroups were created in 5-year intervals up to $25+$ years of experience; $0-5$ years of experience $(n=114), 6$ 10 years of experience $(n=167), 11-15$ years of experience $(n=72), 16-20$ years of experience $(n=23), 21-25$ years of experience $(n=18)$, and $25+$ years of experience $(n=68)$. Each $C C$ was analyzed individually for each subgroup to find key similarities and differences to determine if any trends existed. Each $\mathrm{CC}$ item was tested for homogeneity of variance, then, following ANOVA analysis, a post-hoc Bonferoni analysis to compare subgroups was administered if a main effect was detected. Significance was set a priori at $a<0.05$. A composite mean was achieved by taking the mean from each item inside of the $\mathrm{CC}$ to find the overall perception of importance and use in clinical practice.

RESULTS (note: all tables and Figure 1 are located at the end of this document) Participants generally agreed or strongly agreed that the CCs were important in their clinical practice (Tables 1-6). ATs strongly agreed that PCC was an important aspect of their clinical practice (Composite Mean $=3.59 \pm .63$, Mode $=4$ ) and used it during $85.0 \% \pm 21.8$ of their patient encounters. EBP had the lowest perceived value in clinical practice, (Composite Mean $=3.38 \pm .58$, Mode $=3)$ although it was still frequently used $(73.3 \% \pm 25.6)$ within patient care. ATs agreed that IPCP practice was an important part of their clinical practice (Composite Mean $=3.42 \pm .68$, Mode $=3$ ) with a frequency of use being the second lowest CC $(67.0 \%$ \pm 27.7 ) applied during patient encounters. ATs agreed that HIT was an important aspect of their clinical practice (Composite Mean $=3.21 \pm .66$, Mode $=3$ ) with a frequency of use of $70.8 \% \pm 28.9$ of patient encounters. Participants strongly agreed that QI was an important aspect of their clinical practice (Composite Mean $=3.42 \pm .56$, Mode $=4$ ); however, it was the least used in patient encounters with a frequency of use of $66.1 \% \pm 26.27$ (Table 1). ATs also strongly agreed that PROF was an important aspect of their clinical practice (Composite Mean $=3.42 \pm .562$, Mode $=4$ ) with a frequency of use of $85.9 \% \pm 22.9$ of patient encounters. We identified significant differences between ATs of various years of experience on their perception of how their educational experience prepared them to integrate the CC into practice (Table 7, Figure 1). EBP, QI, and PCC showed the greatest differences between subgroups respectively.

Some specific questions within the survey showed very low perceived agreement. Under the PROF perception portion of the survey, participants disagreed with the statement "I am competent in collaboratively practicing with an endocrinologist about transgender patients who undergo drug-screening process" (Mean $=2.35 \pm .92$, Mode $=2$, Table 2 ). When asked about their perceptions under HIT, participants generally agreed with, but had a low mean score to the statement, "I understand the differences between the electronic health records (EHR) and electronic medical records (EMR) within the context of the stakeholders (providers, patients, payers)" (Mean $=2.87 \pm .81$, Mode $=3$, Table 3). Responding to IPCP questions, respondents disagreed to the statement "I work within a true collaborative practice that has no hierarchy" (Mean $=2.56 \pm .83$, Mode $=2)$, Table 4). Participants disagreed with the statement under the PCC section, "I utilize information from patient surveys to assess the quality of care that I provide" (Mean $=2.71 \pm .88$, Mode $=2$, Table 6 ). Also, under the PCC section, participants disagreed with the statement, "I provide my patients with access to real-time electronic information regarding their care" (Mean $=2.74 \pm .856$, Mode $=2$ ). Again, under the PCC subsection, participants agreed with the statement but had a low mean score to "I use patient-reported outcomes within my clinical practice" (Mean $=2.70 \pm .86$, Mode $=3$, Table 6$)$. 


\section{DISCUSSION}

In this study, ATs either strongly agreed or agreed that the application of CCs within their clinical practice was important, and they often used these CCs within patient encounters. There were significant differences in how ATs with various years of experience perceived how their education prepared them to apply the CCs in clinical practice. QI, HIT, and IPCP were CCs that were used less frequently in practice, which is similar results in other findings. ${ }^{19-23}$

We identified significant differences between the of $0-5$ years of experience group and 25+ years of experience group for preparedness from their academic programs in every CC. There are also significant differences in CC preparedness from programs between the 6-10 years of experience group and 25+ years of experience group in PCC, EBP, and HIT. A likely contributing factor of this phenomenon could be the recent educational programs' curricular updates. The CAATE implemented EBP standards for professional programs in 201124 and PCC standards in post-professional programs and residencies 2014 and 2016 respectively. ${ }^{25,26}$ It is not until the 2020 educational standards were implemented (July 2020) that the CAATE mandated integration of the CCs for the professional degree. ${ }^{3}$ As ATs entering clinical practice have more instruction within their educational experience focused on CC, we could see improved perception and frequency of use among young clinicians.

Within this research, we see there is a lack of perceived ability to incorporate certain aspects of IPCP, QI, EBP, PCC, and HIT regardless of experience levels. There are perceived challenges due to hierarchy, lack of IPCP for transgendered patients, a lack of use of an electronic medical record, and ability to give real time electronic medical data within all of the subgroups. The CCs are intended to be intertwined, so in order to be competent in one, the provider must also be adept at all of them. ${ }^{19}$

Previous research shows a lack of knowledge and use in patient rated outcome measures and electronic documentation systems, which would be categorized under QI, HIT, PCC, and EBP. 22,27 We continue to see a lack of use and perceived importance compared to other CCs among practicing ATs. In two questions particularly, we see a lack of perceived understanding surrounding the use and understanding between an electronic health record (EHR) and an electronic medical record (EMR), as well as the inability to provide real time data to support the patient's care plan. Eberman et al. found that only one third of secondary school athletic trainers used EHRs within their clinical practice. ${ }^{28}$ Furthermore, the NATA has developed "Best Practice Guidelines for Athletic Training Documentation" which includes EHR documentation in all clinical settings. ${ }^{29} \mathrm{It}$ has been shown through research that ATs do not use medical documentation systems ${ }^{28}$, and this data shows that ATs have a lack of perception of using this in their clinical practice. ATs must move into the $21^{\text {st }}$ century with medical documentation in order to provide comprehensive health care to their patient panel. A solution to this problem could be finding an EHR that works within a clinical setting and learning the system may be the first step to improving documentation. Then, professional development must be implemented for ATs to use these records to provide real time data to promote patient's treatment plan.

ATs have been shown to have a fairly positive perception when treating lesbian, gay, bisexual, transgender, or queer patients. 30,31 However, we found that athletic trainers generally disagreed with their ability to collaborate with an endocrinologist when treating transgender patients. This is consistent with other AT literature. ${ }^{30,31}$ The NATA LGTBQ+ Advisory Committee wrote an article for the NATA about "Caring for a Transgender Patient." 32 In this article, reviewing national policy, reviewing the health care facility policies and familiarizing with nomenclature and collaborating with other allied health professionals are the first steps when treating transgendered patients. ${ }^{32}$ We continue to see a positive perception of active transgender patients, but a lack of awareness of how to effectively treat this patient population. . $^{30} 32$

We found that ATs generally disagreed when prompted with "I work within a true collaborative practice that has no hierarchy." We see consistency in this answer in other research related to AT burnout. ${ }^{33}$ There are many factors which are involved when referencing athletic trainer burnout. One of the predominant factors is organizational hierarchy and "politics and bureaucracy" associated with the athletic training profession. ${ }^{33}$ Organizational leadership and comraderies along with ATs being effective communicators are important for reducing AT burnout. ${ }^{33,34}$ We continue to see high burnout rates in athletic training, especially in females. ${ }^{33}$ Developing IPCP skills surrounding patient care, reducing hierarchy, and improving comraderies within health care systems could impact AT burnout.

In studies among athletic training students, findings revealed the number of patient encounters a student engaged in led to better implementation the CCs. ${ }^{20,21}$ This would indicate in an educational setting, more encounters with instruction and reflection improves the ability to use CCs in clinical practice. Interestingly, our findings revealed that the more clinically experienced the AT, the less they perceive the importance and frequency of use of those CCs within their clinical practice. According to our data in professional clinical practice, the more patient encounters, presumably through the greater years of experience, the less perceived importance and frequency is placed in using the CCs. There could be some barriers to more experienced ATs perception of CCs. Some of 
these ATs may have been in practice before they were established in 2001. ${ }^{7}$ Students having formal educational standards for core competencies and the ability to use these within practice shows that with more education and foundational learning, ${ }^{19,20}$ ATs may be able to implement and use these within their own clinical practice more effectively. Creating professional development opportunities similar to those in educational curriculum may be an answer to bridging the gap of perceptions of CCs within multiple subgroups of ATs. By providing clinical ATs modules and building blocks of application, then doing assessments and comprehensive feedback may provide similar improvements on perception and application to clinical practice.

To improve clinical ATs perception and frequency of use of core competencies, we must provide opportunities to learn and integrate these skills into clinical practice. There is precedent for how this could work for practicing ATs. EBP was first introduced as a required component of didactic curriculum for athletic training students in 2011 through the Athletic Training Education Competencies $5^{\text {th }}$ edition. ${ }^{24}$ Since that time, EBP has seen additional emphasis in athletic training. The BOC requirements for professional development first directed professionals to obtain 10 continuing education units in the category of EBP every 2 years during the 2015 reporting cycle. ${ }^{35}$ Since that time, knowledge and perceptions of EBP has improved in ATs. ${ }^{36}$ Within the data of this research, we found EBP had high frequency of use during patient encounters. This would indicate that putting an emphasis of $\mathrm{CC}$ within professional development could improve frequency of use in clinical practice.

Other health care professions have researched how to teach CCs to clinicians with the goal of implementation into practice. ${ }^{17}$ The recommendations given are 1) use building blocks of information that allow for growth over time 2) use a database for individuals to track their progress and find resources on the content and 3) create formative and summative assessment tools to track learners' progress. ${ }^{17}$ Having multiple blocks of educational opportunities that integrate and build confidence and experience over time has been shown to improve clinical use of $\mathrm{CCs} .{ }^{37} \mathrm{It}$ is imperative that professional development builds upon itself and there is consistent assessment and feedback of progress of the learner to transition the learning into clinical practice. 17,37 There also appears to be a strong correlation between an individuals' ability to integrate professional development into clinical practice and their workplace culture and support. $17,37,38$

We have identified QI, IPCP, and HIT as the CCs ATs consistently perceive to be their lowest priority and fundamental ability to implement in clinical practice. Other health care professionals have implemented these changes in curricula as well as professional development with improved actual frequency of use and standardizing patient care. ${ }^{14,16,17}$ Athletic training has begun to shift their continuing education standards to a more comprehensive approach. The BOC has implemented a non-mandatory Professional Development Needs Assessment (PDNA) in March 2021. This PDNA allows the individual AT to take assessments on the domains of the BOC to observe strengths and weaknesses in their clinical practice. Implementing a similar assessment for CCs could provide similar insight to the individual AT.

A consensus statement and systematic review for all health care professionals recommends that "researchers should identify, and if necessary develop, specific assessment tools (both formative and summative) that provide accurate, reliable, and timely evaluation of the CCs of learners." ${ }^{17}$ They continue to recommend that as a clinician gains experience and new technologies arise, professional development may need to change based on the learner's needs. ${ }^{17}$ More experienced ATs showed significantly less perceived importance to their clinical practice in HIT, QI, and EBP principles than did their less experienced counterparts. A lack of understanding how to use technology, financial restrictions, and a lack of information technology professionals who could effectively teach clinicians about HIT systems have been identified impediments to adopting proper HIT standards. ${ }^{39}$ This could be why younger professionals perceive a higher competence and frequency of use for CCs that incorporate informational technology as they are more comfortable with technology.

As health care professionals, ATs should aspire to consistently implement the health care competencies set forth by the NAM. ${ }^{7}$ The CCs give a framework for health care providers to provide equitable, cost effective, and efficient care. With the knowledge that it takes roughly 17 years for research to become main-stream practice, ${ }^{18}$ all health care providers should be well versed and actively using the CCs within their clinical practice. There are perceived gaps among ATs in their perceptions and frequency of use within CCs by experience. By improving the perceptions and frequency of use of CCs within athletic training we can continue to show progress towards implementing the NAM standards. Without reframed professional development, the gap between new professionals and experienced ATs will continue to grow.

\section{Limitations}

There were some limitations involved with this study. During the data collection process, the Covid-19 pandemic may have impacted response rates due to ATs lack of work and resources. Participants were asked for their perceptions of how they use aspects of a specific $\mathrm{CC}$ within their clinical practice. It has been shown that self-assessment of a patient encounter and actual use 
of clinical skills and judgments are skewed and over-reported, especially in younger clinicians. ${ }^{40}$ We must acknowledge the limited number of responses in ATs with 15-25+ years of experience may not be representative of all ATs within that range of experience. Future research should be conducted to objectively measure an AT's ability to use the core competencies throughout patient encounters, instead of through self-report. Future research should also build on effective approaches to disseminating educational content that results in clinical application for ATs.

\section{CONCLUSIONS}

As athletic training continues to adapt to the health care landscape, individual ATs must remain competent. Using the CCs within clinical practice will help ATs continue to serve their patients better. ATs should use the BOC PDNA ${ }^{41}$ to assess their strengths and weaknesses in the Domains of Athletic Training, and use that analysis to develop their PD to improve their clinical practice. There should also be foundational building blocks of PD that include assessment and feedback to the learner with direct application to clinical practice specific to the CCs.

\section{References}

1. Weidner TG, Henning JM. Historical Perspective of Athletic Training Clinical Education. J Athl Train. 2002;37(4 Suppl):S222-S228. [PMID: 12937549]

2. Delforge GD, Behnke RS. The history and evolution of athletic training education in the United States. J Athl Train. 1999;34(1):53-61. [PMID: 16558550]

3. Implementation and Guide to the CAATE 2020 Professional Standards. In. https://caate.net:: Commission on Accreditation of Athletic Training Education 2018:43.

4. Commission on Accreditation of Athletic Training Education. 2020 Standards for the Accreditation of Professional Athletic Training Programs Master's Degree Programs. In. www.caate.net.

5. Profile of Athletic Trainers. National Athletic Trainers' Association. Published 2016. Accessed 8/30/2020, 2020.

6. Board of Certification. BOC Standards of Professional Practice version 3. Published 2018. Accessed 8/30/2020.

7. Institute of Medicine Committee on Quality of Health Care in America: Crossing the Quality Chasm: A New Health System for the 21st Century. Washington (DC): National Academies Press (US); 2001. [PMID: 25057539]

8. Bodenheimer $T$, Sinsky $C$. From triple to quadruple aim: care of the patient requires care of the provider. Ann Fam Med. 2014;12(6):573-576. [PMID: 25384822]

9. Berwick DM, Nolan TW, Whittington J. The Triple Aim: Care, Health, And Cost. Health Affairs. 2008;27(3):759-769. [PMID: 18474969]

10. CAATE Standards for the Accredidation of Professional Athletic Training Programs. In. 2/16/2018 ed. [https://caate.net/pp-standards/: Commission of Accreditation of Athletic Trianing Education; 2018:16.

11. Standards and Required Elements for Accreditation of Physical Therapist Education Programs. In. December 17, 2017 ed. www.capteonline.org/: The Commission on Accreditation in Physical Therapy Education; 2017.

12. Competencies for the Physician Assistant Profession. In. 2012 ed. www.aapa.org/: Accreditation Review Commission on Education for the Physician Assistan; 2012.

13. Brosky JA, Scott R. Professional Competence in Physical Therapy. J Allied Health. 2007;36(2):113-118. [PMID: 27246149]

14. Fouche C, Kenealy T, Mace J, Shaw J. Practitioner perspectives from seven health professional groups on core competencies in the context of chronic care. J Interprof Care. 2014;28(6):534-540. [PMID: 24828623]

15. McKeon LM, Norris T, Cardell B, Britt T. Developing patient-centered care competencies among prelicensure nursing students using simulation. J Nurs Educ. 2009;48(12):711-715. [PMID: 20000255]

16. Spielman Al, Fulmer T, Eisenberg ES, Alfano MC. Dentistry, nursing, and medicine: a comparison of core competencies. J Dent Educ. 2005;69(11):1257-1271. [PMID: 16275689]

17. Albarqouni L, Hoffmann T, Straus S, et al. Core Competencies in Evidence-Based Practice for Health Professionals: Consensus Statement Based on a Systematic Review and Delphi Survey. JAMA Network Open. 2018;1(2):e180281e180281. [PMID: 30646073]

18. Balas EA, Boren, S. A. . Managing Clinical Knowledge for Health Care Improvement. Yearb Med Inform. 2000;09(01):65-70. [PMID: 27699347]

19. Welch Bacon CE, Van Lunen BL, Hankemeier DA. Postprofessional Athletic Training Students' Perceptions Concerning the Health Care Competencies. Athletic Training Education Journal. 2018;13(4):309-323.

20. Cavallario JM, Van Lunen BL, Hoch JM, Hoch M, Manspeaker SA, Pribesh SL. Athletic Training Student Core Competency Implementation During Patient Encounters. J Athl Train. 2018;53(3):282-291. [PMID: 29420058]

21. Cavallario JM, Van Lunen BL, Manspeaker SA. Effect of Procedure Type on Core Competency Implementation by Athletic Training Students. Athletic Training Education Journal. 2019;14(3):208-214. [PMID: 29420058] 
22. Lam KC, Harrington KM, Cameron KL, Valier ARS. Use of Patient-Reported Outcome Measures in Athletic Training: Common Measures, Selection Considerations, and Practical Barriers. J Athl Train. 2019;54(4):449-458. [PMID: 30933607]

23. Sauers ADL, Sauers EL, Valier ARS. Quality Improvement in Athletic Health Care. J Athl Train. 2017;52(11):10701078. [PMID: 29125782]

24. National Athletic Trainers' Association. Athletic Training Educational Competencies 5th Edition. 2011.

25. Commission on Accreditation of Athletic Training Education(CAATE).Standards for the Accreditation of PostProfessionalAthletic Training Degree Programs. Austin TC.

26. Education(CAATE). CoAoAT. Standards for the Accreditation of Post-ProfessionalAthletic Training Degree Programs. Austin, TX: CAATE; . 2013.

27. Valier ARS, Jennings AL, Parsons JT, Vela LI. Benefits of and Barriers to Using Patient-Rated Outcome Measures in Athletic Training. J Athl Train. 2014;49(5):674-683. [PMID: 25098654]

28. Eberman LE, Neil ER, Nottingham SL, Kasamatsu TM, Welch Bacon CE. Athletic Trainers' Practice Patterns Regarding Medical Documentation. J Athl Train. 2019;54(7):822-830. [PMID: 31386576]

29. Thompson C MA, Buffum $P$, et al. . Best practice guidelines for athletic training documentation. https://www.nata.org/sites/default/files/best-practice-guidelines-for-athletic-training-documentation.pdf. Accessed March 6, 2021.

30. Nye EA, Crossway A, Rogers SM, Games KE, Eberman LE. Lesbian, Gay, Bisexual, Transgender, and Queer Patients: Collegiate Athletic Trainers' Perceptions. J Athl Train. 2019;54(3):334-344. [PMID: 30741562]

31. Walen DR, Nye EA, Rogers SM, et al. Athletic Trainers' Competence, Education, and Perceptions Regarding Transgender Student-Athlete Patient Care. J Athl Train.2020;55(11):1142-1152. [PMID: 32905594]

32. Higgins C. Caring for a Transgender Patient 2018. https://www.nata.org/blog/claire-higgins/caring-transgender-patient. Published June 18, 2020. Accessed March 6, 2021.

33. Oglesby LW, Gallucci AR, Wynveen CJ. Athletic Trainer Burnout: A Systematic Review of the Literature. J Athl Train. 2020;55(4):416-430. [PMID: 32196380]

34. Mazerolle SM, Eason CM, Goodman A. Organizational Infrastructure in the Collegiate Athletic Training Setting, Part I: Quality-of-Life Comparisons and Commonalities Among the Models. J Athl Train. 2017;52(1):12-22. [PMID: 27874297]

35. Certification maintenance for certified athletic trainers: compliance requirements for maintaining BOC certification. Board of Certicication for Athletic Trainers. https://www.bocatc.org/athletic-trainers/maintain-certification/continuingeducation/continuing-education. Published 2020. Accessed 11/15/2020, 2020.

36. Manspeaker SA, Hankemeier DA. Athletic Trainers' Current Knowledge and Envisioned Use of Foundational EvidenceBased Practice Concepts. Athletic Training Education Journal. 2017;12(2):121-133.

37. Melnyk BM, Gallagher-Ford L, Long LE, Fineout-Overholt E. The Establishment of Evidence-Based Practice Competencies for Practicing Registered Nurses and Advanced Practice Nurses in Real-World Clinical Settings: Proficiencies to Improve Healthcare Quality, Reliability, Patient Outcomes, and Costs. Worldviews Evid Based Nurs. 2014;11(1):5-15. [PMID: 24447399]

38. Manley K, Martin A, Jackson C, Wright T. A realist synthesis of effective continuing professional development (CPD): A case study of healthcare practitioners' CPD. Nurse Educ Today. 2018;69:134-141. [PMID: 30059819]

39. Hersh WR, Bhupatiraju RT, Greene P, Smothers V, Cohen C. Adopting e-learning standards in health care: competency-based learning in the medical informatics domain. AMIA Annu Symp Proc. 2006:334-338. [PMID: 17238358]

40. Fenske CL, Harris MA, Aebersold ML, Hartman LS. Perception versus reality: a comparative study of the clinical judgment skills of nurses during a simulated activity. J Contin Educ Nurs. 2013;44(9):399-405. [PMID: 23822102]

41. Professional Development Needs Assessment. Board of Certification. https://www.bocatc.org/athletic-trainers/ceresources/professional-development-needs-assessment/professional-development-needs-assessment-overview. Published 2021. Accessed March 12, 2021, 2021. 
Table 1: Quality Improvement Core Competency Perceptions

\begin{tabular}{|c|c|c|c|c|c|c|c|c|}
\hline Core Competency Perception & $\begin{array}{l}n \text { Valid } \\
\text { (Missing) }\end{array}$ & Mean & SD & Mode & $\begin{array}{l}\text { Strongly } \\
\text { Disagree }(\%)\end{array}$ & Disagree $(\%)$ & Agree $(\%)$ & $\begin{array}{l}\text { Strongly } \\
\text { Agree }(\%)\end{array}$ \\
\hline $\begin{array}{l}\text { I provide patient care to ensure that each person associated with the care is engaged } \\
\text { in the process }\end{array}$ & 476 (165) & 3.52 & 0.53 & 4 & $2(.4)$ & $0(0.0)$ & $224(47.1)$ & $250(52.5)$ \\
\hline $\begin{array}{l}\text { I promote effective communication with all of the patient's health care providers to } \\
\text { ensure that the patient gets the care and support he/she needs and wants }\end{array}$ & $476(165)$ & 3.48 & 0.55 & 4 & $0(0.0)$ & $13(2.7)$ & $222(46.6)$ & $241(50.6)$ \\
\hline $\begin{array}{l}\text { I promote effective coordination of care with all of the patient's health care providers } \\
\text { to ensure that the patient gets the care and support he/she needs and wants }\end{array}$ & $475(166)$ & 3.43 & 0.60 & 4 & $2(0.4)$ & $22(4.6)$ & $223(46.9)$ & $228(52.0)$ \\
\hline $\begin{array}{l}\text { I provide care that is in the best interest of the patient, avoids further injury to the } \\
\text { patient, and is intended to help them }\end{array}$ & $475(166)$ & 3.73 & 0.48 & 4 & $3(0.6)$ & $0(0.0)$ & $118(24.8)$ & $354(74.5)$ \\
\hline $\begin{array}{l}\text { I promote prevention approaches to care rather than to only providing care as injuries } \\
\text { occur }\end{array}$ & $474(167)$ & 3.42 & 0.62 & 4 & $3(0.6)$ & $24(5.1)$ & $219(46.2)$ & $228(52.0)$ \\
\hline $\begin{array}{l}\text { I provide patient centered care that is respectful of, and responsive to, an individual } \\
\text { patient's preferences, needs, and values to ensure that the patient's values guide all } \\
\text { clinical decisions }\end{array}$ & 475 (166) & 3.6 & 0.52 & 4 & $1(0.2)$ & $3(0.6)$ & $180(37.9)$ & 291 (61.3) \\
\hline $\begin{array}{l}\text { I manage care by initially determining what the problem is and identifying the facts } \\
\text { about the problem }\end{array}$ & 475 (166) & 3.57 & 0.54 & 4 & $1(0.2)$ & $7(1.5)$ & $187(39.4)$ & $280(58.9)$ \\
\hline $\begin{array}{l}\text { I focus on the use of data to analyze processes, identify problems, and measure } \\
\text { performance }\end{array}$ & $476(165)$ & 2.96 & 0.59 & 3 & $3(0.6)$ & $83(17.4)$ & $319(67.0)$ & $71(14.9)$ \\
\hline $\begin{array}{l}\text { I understand athletic training care is a part of the healthcare system and a process } \\
\text { that provides documented information that will be of value to other organizations }\end{array}$ & 475 (166) & 3.58 & 0.52 & 4 & $1(0.2)$ & $3(0.6)$ & $192(40.4)$ & $279(58.7)$ \\
\hline $\begin{array}{l}\text { I am able to identify defects in quality of care and trace them to the source to avoid } \\
\text { similar problems in the future (i.e., continuous improvement) }\end{array}$ & 474 (167) & 3.19 & 0.58 & 3 & $4(0.8)$ & $30(6.3)$ & $311(65.6)$ & $129(27.2)$ \\
\hline $\begin{array}{l}\text { I am able to empower the healthcare workforce around me in order to help co-workers } \\
\text { embrace ownership of the care they provide }\end{array}$ & 474 (167) & 3.18 & 0.66 & 3 & $3(0.6)$ & $58(12.2)$ & $262(55.3)$ & $151(31.9)$ \\
\hline $\begin{array}{l}\text { I am able to assist with the creation of an environment that is committed to quality, } \\
\text { teamwork, and accountability }\end{array}$ & 475 (166) & 3.43 & 0.57 & 3 & $2(0.4)$ & $12(2.5)$ & $243(51.2)$ & $218(45.9)$ \\
\hline
\end{tabular}

(C) The Internet Journal of Allied Health Sciences and Practice, 2021 


\begin{tabular}{|c|c|c|c|c|c|c|c|c|}
\hline Core Competency Perception & $\begin{array}{c}\mathrm{n} \text { Valid } \\
\text { (Missing) }\end{array}$ & Mean & SD & Mode & $\begin{array}{c}\text { Strongly } \\
\text { Disagree (\%) }\end{array}$ & Disagree (\%) & Agree (\%) & $\begin{array}{c}\text { Strongly } \\
\text { Agree (\%) }\end{array}$ \\
\hline $\begin{array}{l}\text { I am able to recognize when there is a conflict of interest between myself, my } \\
\text { patients, and my clinical practice }\end{array}$ & $456(185)$ & 3.44 & 0.536 & 3 & $1(0.2)$ & $6(1.3)$ & $239(52.4)$ & $210(46.1)$ \\
\hline I am able to resolve conflicts between my interests and the patients' interests & $457(184)$ & 3.39 & 0.514 & 3 & $1(0.2)$ & $3(0.7)$ & $270(59.1)$ & $183(44.7)$ \\
\hline $\begin{array}{l}\text { I am able to consistently place the interest of the individual patient and society } \\
\text { above my own }\end{array}$ & $456(185)$ & 3.54 & 0.517 & 4 & $0(0.0)$ & $4(0.9)$ & $204(44.7)$ & $248(54.4)$ \\
\hline $\begin{array}{l}\text { I exercise accountability for myself and for my colleagues in providing patient } \\
\text { care and consider the financial impact of our decisions }\end{array}$ & 457 (184) & 3.46 & 0.588 & 4 & $2(0.4)$ & $16(3.5)$ & $207(45.3)$ & $232(50.8)$ \\
\hline $\begin{array}{l}\text { I am able to protect patients against unprofessional, incompetent, or unethical } \\
\text { conduct concerning other healthcare professionals }\end{array}$ & $456(185)$ & 3.29 & 0.684 & 3 & $4(0.9)$ & $47(10.3)$ & $216(47.4)$ & $189(41.4)$ \\
\hline $\begin{array}{l}\text { I respect other healthcare professionals that I work with and recognize their } \\
\text { unique skills and }\end{array}$ & $453(188)$ & 3.67 & 0.48 & 4 & $0(0.0)$ & $2(0.4)$ & $145(32.0)$ & $306(67.5)$ \\
\hline $\begin{array}{l}\text { I am competent in collaboratively practicing with an endocrinologist about } \\
\text { transgender patients who undergo drug-screening processes. }\end{array}$ & $452(189)$ & 2.35 & 0.919 & 2 & $81(17.9)$ & $189(41.8)$ & $124(27.4)$ & $58(12.8)$ \\
\hline $\begin{array}{l}\text { I demonstrate a continuing commitment to excellence through the dissemination } \\
\text { of new knowledge in athletic training to fellow athletic trainers, patients, and } \\
\text { other healthcare professionals }\end{array}$ & $452(189)$ & 3.39 & 0.535 & 3 & $0(0.0)$ & $11(2.4)$ & $255(56.4)$ & $186(41.2)$ \\
\hline $\begin{array}{l}\text { I maintain competence in the body of knowledge in athletic training that I am } \\
\text { responsible for and I have a commitment to lifelong learning, which will enhance } \\
\text { my clinical practice }\end{array}$ & $452(189)$ & 3.61 & 0.493 & 4 & $0(0.0)$ & $1(0.2)$ & $174(38.5)$ & 277 (61.3) \\
\hline $\begin{array}{l}\text { I practice in a legally competent manner by conforming to the laws that govern } \\
\text { athletic training within my state and I understand the consequences of violating } \\
\text { these laws }\end{array}$ & 451 (190) & 3.72 & 0.455 & 4 & $0(0.0)$ & $1(0.2)$ & $125(27.7)$ & $325(72.1)$ \\
\hline $\begin{array}{l}\text { I practice a healthy lifestyle in which I maintain an equal work-life balance ratio } \\
\text { while being cognizant of internal and external stressors }\end{array}$ & 454 (187) & 3.06 & 0.762 & 3 & $9(2.0)$ & $91(20.0)$ & $216(47.6)$ & $138(30.4)$ \\
\hline $\begin{array}{l}\text { I demonstrate sensitivity to multiple cultures through my awareness of the } \\
\text { impact of patients' cultural differences on their attitudes and behaviors toward } \\
\text { healthcare }\end{array}$ & 449 (192) & 3.54 & 0.503 & 4 & $0(0.0)$ & $1(0.2)$ & $205(45.7)$ & $243(54.1)$ \\
\hline $\begin{array}{l}\text { I demonstrate the knowledge, attitudes, beliefs and skills necessary to achieve } \\
\text { optimal health outcomes for diverse patient populations }\end{array}$ & 446 (195) & 3.49 & 0.522 & 4 & $0(0.0)$ & $5(1.1)$ & $219(49.1)$ & $222(49.8)$ \\
\hline I know and apply the commonly accepted standards for patient confidentiality & $448(193)$ & 3.68 & 0.473 & 4 & $0(0.0)$ & $1(0.2)$ & $143(31.9)$ & $304(67.9)$ \\
\hline $\begin{array}{l}\text { I reflect critically upon my actions and decisions and strive for improvement in } \\
\text { all aspects of my work }\end{array}$ & $448(193)$ & 3.65 & 0.5 & 4 & $0(0.0)$ & $5(1.1)$ & $146(32.6)$ & $297(66.3)$ \\
\hline I demonstrate effective interpersonal communication skills & 447 (194) & 3.51 & 0.522 & 4 & $0(0.0)$ & $5(1.1)$ & $209(46.8)$ & $233(52.1)$ \\
\hline I receive and respond well to critiques from peers, colleagues, and superiors & $446(192)$ & 3.37 & 0.537 & 4 & $0(0.0)$ & $12(2.7)$ & $256(57.4)$ & $178(39.9)$ \\
\hline
\end{tabular}


Table 3: Healthcare Informatics and Technology Core Competency Perceptions

\begin{tabular}{|c|c|c|c|c|c|c|c|c|}
\hline Core Competency Perception & $\begin{array}{l}\text { n Valid } \\
\text { (Missing) }\end{array}$ & Mean & SD & Mode & $\begin{array}{c}\text { Strongly } \\
\text { Disagree (\%) }\end{array}$ & Disagree (\%) & Agree (\%) & $\begin{array}{l}\text { Strongly } \\
\text { Agree (\%) }\end{array}$ \\
\hline $\begin{array}{l}\text { I understand the terminology used in informatics (informatics, medical } \\
\text { informatics, health informatics, consumer health informatics, clinical health } \\
\text { informatics, computer literacy, information literacy, medical terminology }\end{array}$ & $426(215)$ & 3.11 & 0.648 & 3 & $4(.9)$ & $56(13.1)$ & $254(59.6)$ & $112(26.3)$ \\
\hline $\begin{array}{l}\text { I understand the differences between the Electronic Health Records (EHR) and } \\
\text { Electronic Medical Records (EMR) within the context of the stakeholders } \\
\text { (providers, patients, payers) }\end{array}$ & $428(213)$ & 2.87 & 0.814 & 3 & $14(3.3)$ & $130(30.4)$ & $180(42.1)$ & $104(24.3)$ \\
\hline $\begin{array}{l}\text { I use computerized patient records to develop clinical questions and to support } \\
\text { my plan of care }\end{array}$ & $427(214)$ & 3.03 & 0.784 & 3 & $16(3.7)$ & $76(17.8)$ & $213(49.9)$ & $122(28.6)$ \\
\hline $\begin{array}{l}\text { I have the ability to process, interpret and understand data which is collected to } \\
\text { support patient care and decision making }\end{array}$ & 427 (214) & 3.19 & 0.601 & 3 & $2(.5)$ & $38(8.9)$ & $264(61.8)$ & $123(28.8)$ \\
\hline $\begin{array}{l}\text { I use standardized terminology that facilitates communication and sharing of } \\
\text { information across providers and across professions }\end{array}$ & $427(214)$ & 3.32 & 0.546 & 3 & $1(.2)$ & $14(3.3)$ & $259(60.7)$ & 153 (35.8) \\
\hline I follow security and confidentiality precautions in order to protect patient privacy & $420(221)$ & 3.63 & 0.493 & 4 & $0(0.0)$ & $2(.5)$ & $151(36.0)$ & $267(63.6)$ \\
\hline $\begin{array}{l}\text { I am an active participant in the decisions concerning the utilization and } \\
\text { development of our clinical information system within the clinical practice setting }\end{array}$ & $419(222)$ & 3.08 & 0.836 & 3 & $19(4.5)$ & $74(17.7)$ & $181(43.2)$ & $145(34.6)$ \\
\hline $\begin{array}{l}\text { I understand that healthcare information is a continual and multifaceted process } \\
\text { that should be used to validate or change my clinical practice }\end{array}$ & $418(223)$ & 3.52 & 0.533 & 4 & $1(.2)$ & $4(.9)$ & $189(45.2)$ & $224(53.6)$ \\
\hline
\end{tabular}


Table 4: Interprofessional Collaborative Practice Core Competency Perceptions

\begin{tabular}{|c|c|c|c|c|c|c|c|c|}
\hline Core Competency Perception & $\begin{array}{c}\text { n Valid } \\
\text { (Missing) }\end{array}$ & Mean & SD & Mode & $\begin{array}{c}\text { Strongly } \\
\text { Disagree (\%) }\end{array}$ & Disagree (\%) & Agree (\%) & $\begin{array}{l}\text { Strongly } \\
\text { Agree (\%) }\end{array}$ \\
\hline $\begin{array}{l}\text { I interact with other health professionals to optimize the quality of care provided } \\
\text { to individual patients }\end{array}$ & $414(227)$ & 3.62 & 0.547 & 4 & $3(0.7)$ & $4(1.0)$ & $140(33.8)$ & $267(64.5)$ \\
\hline $\begin{array}{l}\text { I am familiar with the scope of practice of other healthcare professionals with } \\
\text { whom I work }\end{array}$ & $414(227)$ & 3.53 & 0.589 & 4 & $3(0.7)$ & $11(2.7)$ & $164(39.6)$ & $236(57.0)$ \\
\hline $\begin{array}{l}\text { I participate within a healthcare team consisting of individuals with diverse } \\
\text { training and backgrounds that supplement care }\end{array}$ & $414(227)$ & 3.47 & 0.655 & 4 & $6(1.4)$ & $19(4.6)$ & $165(39.9)$ & $224(54.1)$ \\
\hline $\begin{array}{l}\text { I am able to resolve conflicts with my interprofessional healthcare team if there } \\
\text { are diverse set of views }\end{array}$ & $414(227)$ & 3.4 & 0.617 & 3 & $6(1.4)$ & $11(2.7)$ & $208(50.2)$ & $189(45.7)$ \\
\hline I work within a true collaborative practice that has no hierarchy & $408(233)$ & 2.56 & 0.827 & 2 & $32(7.8)$ & $173(42.4)$ & $146(35.8)$ & $57(14.0)$ \\
\hline $\begin{array}{l}\text { I work within a clinical practice setting in which mutual respect is fostered among } \\
\text { the disciplines }\end{array}$ & $407(234)$ & 3.2 & 0.683 & 3 & $5(1.2)$ & $47(11.5)$ & $216(53.1)$ & $139(34.2)$ \\
\hline $\begin{array}{l}\text { I have planned opportunities to collaborate and interact with other health care } \\
\text { students, which enables me to learn new skills and approaches for patient care }\end{array}$ & $406(235)$ & 2.88 & 0.837 & 3 & $18(4.4)$ & $114(28.1)$ & $171(42.1)$ & $103(25.4)$ \\
\hline $\begin{array}{l}\text { I have planned opportunities with other healthcare professionals that benefit my } \\
\text { clinical practice growth }\end{array}$ & $408(233)$ & 3.1 & 0.707 & 3 & $5(1.2)$ & $69(16.9)$ & $216(52.9)$ & $118(28.9)$ \\
\hline
\end{tabular}


Table 5: Evidence Based Practice Core Competency Perceptions

\begin{tabular}{|c|c|c|c|c|c|c|c|c|}
\hline Core Competency Perception & $\begin{array}{c}\mathrm{n} \text { Valid } \\
\text { (Missing) }\end{array}$ & Mean & SD & Mode & $\begin{array}{c}\text { Strongly } \\
\text { Disagree (\%) }\end{array}$ & Disagree (\%) & Agree (\%) & $\begin{array}{l}\text { Strongly } \\
\text { Agree (\%) }\end{array}$ \\
\hline I have adopted an EBP approach to my clinical practice & $401(240)$ & 3.28 & 0.632 & 3 & $3(0.7)$ & $30(7.5)$ & $218(54.4)$ & $150(37.4)$ \\
\hline I utilize Electronic Medical Record (EMR) information to make clinical decisions & $401(240)$ & 3 & 0.832 & 3 & $15(3.7)$ & $94(23.4)$ & $169(42.1)$ & $123(30.7)$ \\
\hline $\begin{array}{l}\text { I believe that literature and research findings are useful in my day-to-day clinical } \\
\text { practice }\end{array}$ & $401(240)$ & 3.3 & 0.599 & 3 & $1(0.2)$ & $27(6.7)$ & $225(56.1)$ & $148(36.9)$ \\
\hline I take my clinical setting into account when making clinical decisions & $401(240)$ & 3.5 & 0.53 & 4 & $0(0.0)$ & $6(1.5)$ & $189(47.1)$ & $206(51.4)$ \\
\hline $\begin{array}{l}\text { I take patient preferences and values into account when making clinical } \\
\text { decisions }\end{array}$ & $400(240)$ & 3.54 & 0.509 & 4 & $0(0.0)$ & $2(0.5)$ & $181(45.3)$ & $217(54.3)$ \\
\hline $\begin{array}{l}\text { I take my clinical expertise and experience into account when making clinical } \\
\text { decisions }\end{array}$ & 402 (239) & 3.64 & 0.491 & 4 & $0(0.0)$ & $2(0.5)$ & $141(35.1)$ & $259(64.4)$ \\
\hline I critically evaluate the outcome of my interventions & $400(241)$ & 3.23 & 0.616 & 3 & $0(0.0)$ & $40(10.0)$ & $227(56.8)$ & $133(33.3)$ \\
\hline $\begin{array}{l}\text { I possess a curiosity and a sense of inquiry that defines me as a life-long } \\
\text { learner }\end{array}$ & $399(242)$ & 3.51 & 0.566 & 4 & $0(0.0)$ & $14(3.5)$ & $167(41.9)$ & $218(54.6)$ \\
\hline $\begin{array}{l}\text { I recognize and understand the limits of science, my knowledge and my skills, } \\
\text { when making a clinical decision }\end{array}$ & 400 (241) & 3.51 & 0.506 & 4 & $0(0.0)$ & $1(0.3)$ & $196(49.0)$ & $203(50.7)$ \\
\hline I engage in continuous quality improvement within my own practice & $399(242)$ & 3.44 & 0.54 & 3 & $0(0.0)$ & $9(2.3)$ & $206(51.6)$ & $184(46.1)$ \\
\hline $\begin{array}{l}\text { I am knowledgeable concerning the mechanisms to access evidence through } \\
\text { institutional databases }\end{array}$ & 399 (242) & 3.21 & 0.628 & 3 & $2(0.5)$ & $40(10.0)$ & $231(57.9)$ & $126(31.6)$ \\
\hline I have the ability to critically appraise evidence in an accurate manner & $399(242)$ & 3.22 & 0.59 & 3 & $0(0.0)$ & $35(8.8)$ & $241(60.4)$ & $123(30.8)$ \\
\hline I understand the role injury and illness can play in the disablement of a patient & $398(243)$ & 3.56 & 0.517 & 4 & $0(0.0)$ & $4(1.0)$ & $169(42.5)$ & $225(56.5)$ \\
\hline
\end{tabular}


Table 6: Patient Centered Care Core Competency Perceptions

\begin{tabular}{|c|c|c|c|c|c|c|c|c|}
\hline Core Competency Perception & $\begin{array}{l}n \text { Valid } \\
\text { (Missing) }\end{array}$ & Mean & SD & Mode & $\begin{array}{l}\text { Strongly } \\
\text { Disagree } \\
(\%)\end{array}$ & Disagree $(\%)$ & Agree (\%) & $\begin{array}{l}\text { Strongly } \\
\text { Agree (\%) }\end{array}$ \\
\hline $\begin{array}{l}\text { I promote a patient-centered healthcare system that gives patients the ability to } \\
\text { communicate effectively and immediately with their providers }\end{array}$ & $388(253)$ & 3.53 & 0.535 & 4 & $0(0.0)$ & $7((1.8)$ & $167(43.0)$ & $214(55.2)$ \\
\hline $\begin{array}{l}\text { I look holistically at an individual and treat them through the coordination of other } \\
\text { providers with shared decision making }\end{array}$ & $388(253)$ & 3.42 & 0.594 & 3 & $1(0.3)$ & $18(4.6)$ & $185(47.7)$ & $184(47.7)$ \\
\hline I utilize information from patient surveys to assess the quality of care that I provide & $388(253)$ & 2.71 & 0.875 & 3 & $28(7.2)$ & $138(35.6)$ & $142(36.6)$ & $80(20.6)$ \\
\hline \multirow{2}{*}{$\begin{array}{l}\text { I provide information to my patients that is important and useful for them } \\
\text { I provide my patients with access to real-time electronic information regarding their } \\
\text { care }\end{array}$} & $388(253)$ & 3.55 & 0.504 & 4 & $0(0.0)$ & $1(0.3)$ & $174(44.8)$ & $213(54.9)$ \\
\hline & $387(254)$ & 2.74 & 0.856 & 2 & $20(5.2)$ & $146(37.7)$ & $137(35.4)$ & $84(21.7)$ \\
\hline I utilize patient-report outcomes within my clinical practice & $388(253)$ & 2.7 & 0.832 & 3 & $22(5.7)$ & $144(37.1)$ & $151(38.9)$ & $71(18.3)$ \\
\hline I provide patient education to self-manage care following discharge & $388(253)$ & 3.46 & 0.572 & 4 & $2(0.5)$ & $9(2.3)$ & $184(47.4)$ & $193(49.7)$ \\
\hline I respond quickly, effectively and safely to patients' needs and wishes & $388(253)$ & 3.55 & 0.503 & 4 & $0(0.0)$ & $1(0.3)$ & $173(44.6)$ & $214(55.2)$ \\
\hline $\begin{array}{l}\text { I treat my patients and their families in a dignified and supportive manner } \\
\text { I provide my patients and their families with evidence-based, cost effective quality }\end{array}$ & $388(253)$ & 3.7 & 0.46 & 4 & $0(0.0)$ & $0(0.0)$ & $117(30.2)$ & $271(69.8)$ \\
\hline $\begin{array}{l}\text { care that maximizes health, alleviates discomfort and is safe and free from } \\
\text { avoidable errors }\end{array}$ & $388(253)$ & 3.53 & 0.535 & 4 & $0(0.0)$ & $7((1.8)$ & $167(43.0)$ & $214(55.2)$ \\
\hline
\end{tabular}

(C) The Internet Journal of Allied Health Sciences and Practice, 2021 
Figure 1: Perception of Preparedness from Professional Program

Perceived Preparedness from Program by Years of Experience and CC

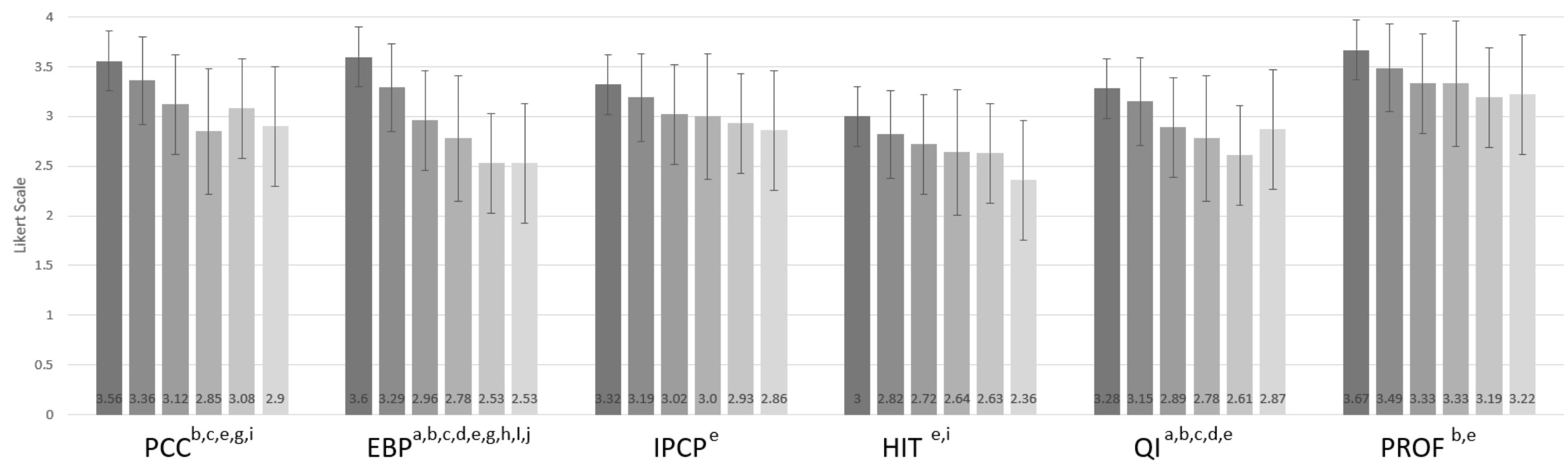

a 0-5 years of experience compared to 6-10 years of experience $\mathrm{b} 0-5$ years of experience compared to $11-15$ years of experience c $0-5$ years of experience compared to $16-20$ years of experience d $0-5$ years of experience compared to 21-25 years of experience e $0-5$ years of experience compared to $25+$ years of experience

f6-10 years of experience compared to $11-15$ years of experience

g 6-10 years of experience compared to $16-20$ years of experience

${ }^{\mathrm{h}} 6-10$ years of experience compared to 21-25 years of experience

16-10 years of experience compared to $25+$ years of experience

j11-15 years of experience compared to $25+$ years of experience 